\title{
Pengaruh Motivasi, Komunikasi dan Lingkungan Kerja Terhadap Semangat Kerja pada PT Global Konstruksi Prakasa Madiun
}

\author{
Jefri Dwi Herdiyansyah ${ }^{1}$, Mintarti Indartini ${ }^{2}$, Novy Rachma Herawati ${ }^{3}$ \\ ${ }^{1}$ Mahasiswa Program Studi Manajemen, Fakultas Ekonomi, Universitas Merdeka Madiun \\ ${ }^{I}$ E-mail: jefridwi@gmail.com \\ ${ }^{2,3}$ Program Studi Manajemen, Fakultas Ekonomi, Universitas Merdeka Madiun \\ ${ }^{2}$ E-mail:mintarti@unmer-madiun.ac.id. \\ ${ }^{3}$ E-mail:novy@unmer-madiun.ac.id.
}

\begin{abstract}
Employee morale is highly dependent on the state of the work environment. The level of employee morale individually will be different depending on each employee's perception of his work. This study aims (1) Does motivation partially affect work morale at PT Global Kontruksi Prakasa Madiun. (2) Does communication partially affect work morale at PT Global Kontruksi Prakasa Madiun. (3) Does the work environment partially affect morale? work at PT Global Kontruksi Prakasa Madiun. (4) Do motivation, communication, and work environment simultaneously affect the morale at PT Global Kontruksi Prakasa Madiun. The population in this study were employees of PT Global Kontruksi Prakasa Madiun during the study period. The sample size in this study amounted to 50 people. The method used in sampling is saturated sample. The research instrument used a questionnaire. The data analysis technique used classical assumption test, multiple linear regression analysis, coefficient of determination analysis, and hypothesis testing using $t$ test and $F$ test. The results showed that (1) Partially, motivation had no effect on morale at PT Global Kontruksi Prakasa Madiun. (2) Partially, communication has no effect on morale at PT Global Kontruksi Prakasa Madiun. (3) Partially the work environment affects the morale of PT Global Kontruksi Prakasa Madiun. (4) Simultaneously, motivation, communication, and work environment affect work morale at PT Global Kontruksi Prakasa Madiun.
\end{abstract}

Keywords-: Motivation; Communication; Work Environment; Work Spirit.

\section{PENDAHULUAN}

Perkembangan era globalisasi menuntut perusahaan untuk dapat menyesuaikan kondisi perusahaan dengan situasi yang ada. Perusahaan dituntut harus dapat mengembangkan setiap sumber daya yang dimiliki secara optimal. Perusahaan diharapkan menjadi suatu organisasi yang efektif dan efisien, agar mampu bersaing dengan para pesaingnya. Keunggulan yang dimiliki perusahaan akan mampu menjadikan perusahaan bertahan di tengah ketatnya persaingan dunia usaha. Sumber daya manusia merupakan salah satu faktor penting yang menjadi tonggak perkembangan suatu perusahaan. Perusahaan memerlukan sumber daya manusia yang terdidik, terampil dan kompeten dibidangnya.

Manajemen perusahaan harus memperhatikan pengelolaan sumber daya manusia perusahaannya. Sumber daya manusia dalam perusahaan diwujudkan oleh semua karyawan perusahaan di setiap lininya. Karyawan dalam melakukan kewajiban atau tugasnya sangat dipengaruhi oleh semangat kerja dari masing-masing individu karyawan tersebut.

Menurut Handoko (2011) sumber daya manusia merupakan salah satu aspek penting dalam perusahaan meliputi orangorang yang memberikan tenaga, bakat, kreativitas dan usaha mereka kepada organisasi atau perusahaan. Suksesnya sebuah organisasi ditentukan oleh kinerja karyawan organisasi tersebut. Kinerja karyawan sangat tergantung pada tingkat semangat kerja karyawan dalam melaksanakan tugas atau kegiatan organisasi.

Menurut Handoko (2011) merumuskan suatu semangat kerja yang menggambarkan suatu perusahaan, ini memang agak berhubungan dengan tabiat (jiwa) semangat kerja kelompok. Untuk kerja kelompok, pekerjaan yang lazim menyatakan bahwa semangat kerja menunjukkan iklim dan suasana pekerja, apabila para pekerja nampaknya mereka senang, maka mereka optimis mengenai kegiatan-kegiatan dan tugas kelompoknya serta ramah dengan satu sama lainnya. Manajemen harus memperhatikan berbagai kemungkinan hal yang terjadi di dalam perusahaannya, terutama yang berkaitan dengan karyawannya.

Menurut Yahyo (2013) "perusahaan dalam meningkatkan kinerja perusahaan harus memperhatikan tingkat semangat kerja karyawannya". Hal ini juga di dukung oleh pernyataan dari Mathis dan Jackson (2006) menyebutkan bahwa "semangat kerja pekerja di China sangat dipengaruhi oleh motivasi para pekerjanya dalam bekerja”. Menurut Munandar dan Darmadi (2018), "motivasi adalah suatu proses dimana kebutuhan mendorong seseorang untuk melakukan serangkaian kegiatan yang mengarah ke tercapainya tujuan tertentu".

Menurut Siagian (2018), "motivasi merupakan daya dorong bagi seseorang untuk memberikan kontribusi yang sebesar 
mungkin demi keberhasilan organisasi mencapai tujuannya".

Selain motivasi, faktor komunikasi menjadi salah satu faktor penting mempengaruhi semangat kerja karyawan. Komunikasi adalah proses pemindahan pengertian dalam bentuk gagasan atau informasi dari seseorang ke orang lain (Handoko, 2013). Menurut Ginting (2017) "komunikasi adalah suatu proses pada seseorang yang berusaha untuk memberikan pengertian dan informasi dengan cara menyampaikan pesan kepada orang lain". Selain itu komunikasi juga dapat dikatakan sebagai proses pembentukan, penyampaian, penerimaan, dan pengolahan pesan yang terjadi di dalam diri seseorang atau diantara dua atau lebih dengan tujuan tertentu (Sinambela, 2015). Komunikasi internal menjadi salah satu faktor pendorong karyawan untuk bekerja dengan sungguh sungguh, serta kompensasi menjadi daya tarik bagi karyawan agar pekerjaannya terselesaikan dengan cepat.

Selain faktor motivasi dan komunikasi, lingkungan kerja tempat suatu perusahaan juga turut menjadi faktor eksternal yang mempengaruhi semangat kerja karyawan. Kondisi fisik dari suatu lingkungan kerja mempunyai pengaruh besar dalam tingkat semangat kerja karyawan. Lingkungan kerja adalah segala suatu hal atau unsur- unsur yang dapat mempengaruhi secara langsung maupun tidak langsung terhadap organisasi atau perusahaan yang akan memberikan dampak baik ataupun buruk terhadap kinerja karyawan (Soetjipto, 2008). Disisi lain lingkungan kerja juga disebut suatu tempat bagi sejumlah kelompok dimana di dalamnya terdapat beberapa fasilitas pendukung untuk mencapai tujuan perusahaan sesuai dengan visi dan misi perusahaan (Sedarmayanti, 2017).

Semangat kerja karyawan sangat tergantung pada keadaan lingkungan kerja mereka. Tingkat semangat kerja karyawan secara individu akan berbeda tergantung pada persepsi masing-masing karyawan akan pekerjaannya. Menurut Pangondian dalam Wirawan (2015) mengemukakan "bahwa sangat penting memperhatikan komunikasi dan lingkungan kerja dalam perusahaan, karena komunikasi dan lingkungan kerja berpengaruh positif terhadap semangat kerja". Dengan adanya komunikasi yang baik dalam dunia kerja akan membawa sebuah instansi maupun organisasi lebih mudah mencapai target. Menjadi jembatan bagi pekerja yang memiliki banyak karakter untuk tetap fokus dan tetap saling menghargai satu sama lain. Berdasarkan penjelasan tersebut, maka peneliti merumuskan hipotesis sebagai berikut:

$\mathrm{H}_{1}$ : Secara parsial motivasi berpengaruh terhadap semangat kerja pada PT Global Kontruksi Prakasa Madiun.

$\mathrm{H}_{2}$ : Secara parsial komunikasi berpengaruh terhadap semangat kerja pada PT Global Kontruksi Prakasa Madiun.

$\mathrm{H}_{3}$ : Secara parsial lingkungan kerja berpengaruh terhadap semangat kerja pada PT Global Kontruksi Prakasa Madiun.

$\mathrm{H}_{4}$ : Secara simultan motivasi, komunikasi, dan lingkungan kerja berpengaruh terhadap semangat kerja pada PT Global Kontruksi Prakasa Madiun.

Maka penelitian ini bertujuan untuk menganalisa pengaruh motivasi secara parsial terhadap semangat kerja pada PT Global Kontruksi Prakasa Madiun. Menganalisa komunikasi secara parsial terhadap semangat kerja pada PT Global Kontruksi PrakasaMadiun. Menganalisa lingkungan kerja secara parsial terhadap semangat kerja pada PT Global Kontruksi Prakasa Madiun. Menganalisa pengaruh motivasi, komunikasi, dan lingkungan kerja secara simultan terhadap semangat kerja pada PT Global Kontruksi Prakasa Madiun.

\section{METODE PENELITIAN}

Metode penelitian ini merupakan penelitian asosiatif kausal dengan menggunakan pendekatan kuantitatif yang berlokasi di PT Global Konstruksi Prakasa Madiun. Dengan jumlah populasi sebanyak 50 responden dan menggunakan teknik sampling jenuh. Pengumpulan data yang dilakukan peneliti melalui data kuesioner, wawancara, dan dokumentasi, serta dilakukan teknik analisa data regresi linier berganda, koefisien determinan, Uji t (parsial), Uji F (simultan)..

\section{III.HASIL DAN PEMBAHASAN}

Uji normalitas bertujuan untuk menguji apakah data variabel terikat, variabel bebas, atau keduanya mempunyai distribusi normal atau tidak. Model regresi yang baik adalah memiliki distribusi data normal, sedangkan distribusi tidak normal diketahui dengan melihat penyebaran data statistik pada sumbu diagonal dari grafik distribusi normal (Ghozali, 2016). Berikut adalah hasil pengujian normalitas sebagai berikut :

Gambar 1.

Hasil Uji Normalitas

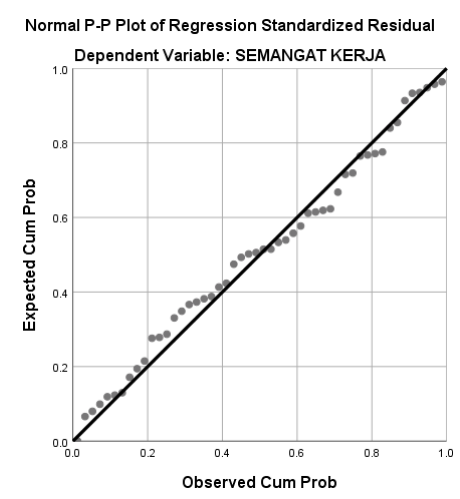


Dapat diketahui bahwa data menyebar disekitar garis diagonal dan mengikuti arah garis diagonal. Dengan demikian dapat disimpulkan bahwa variabel dalam penelitian ini berdistribusi normal.

Tabel 1.

Hasil Uji Multikolinearitas

\begin{tabular}{|c|c|c|c|c|c|c|c|}
\hline \multirow{2}{*}{ Model } & \multicolumn{2}{|c|}{$\begin{array}{c}\text { Unstandardized } \\
\text { Coefficients } \\
\end{array}$} & \multirow{2}{*}{$\begin{array}{c}\begin{array}{c}\text { Standardized } \\
\text { Coefficients }\end{array} \\
\text { Beta }\end{array}$} & \multirow{2}{*}{$\mathrm{t}$} & \multirow{2}{*}{ Sig. } & \multicolumn{2}{|c|}{$\begin{array}{c}\text { Collinearity } \\
\text { Statistics }\end{array}$} \\
\hline & B & Std. Error & & & & Tolerance & VIF \\
\hline (Constant) & 4.580 & 6.952 & & .659 & .513 & & \\
\hline MOTIVASI & .266 & .181 & .145 & 1.474 & .147 & .758 & 1.319 \\
\hline KOMUNIKASI & -.071 & .323 & -.020 & -.221 & .826 & .931 & 1.075 \\
\hline $\begin{array}{l}\text { LINGKUNGAN } \\
\text { KERJA }\end{array}$ & 1.473 & .196 & .738 & 7.523 & .000 & .761 & 1.315 \\
\hline
\end{tabular}

Dapat diketahui bahwa nilai VIF untuk motivasi sebesar 1,319, komunikasi sebesar 1.075 dan lingkungan kerja sebesar 1,315. Karena nilai VIF kurang dari 10, maka dapat disimpulkan bahwa pada model regresi tidak ditemukan adanya masalah multikolinearitas.

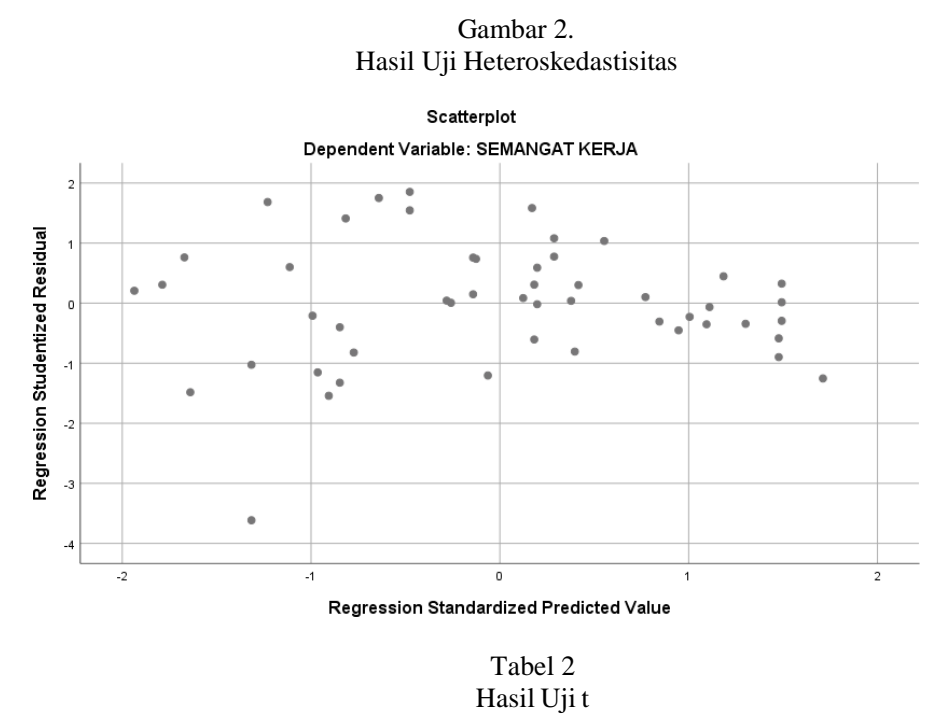

\begin{tabular}{|c|c|c|c|c|c|}
\hline \multirow[b]{2}{*}{ Model } & \multicolumn{2}{|c|}{$\begin{array}{c}\text { Unstandardized } \\
\text { Coefficients }\end{array}$} & \multirow{2}{*}{$\begin{array}{c}\begin{array}{c}\text { Standardized } \\
\text { Coefficients }\end{array} \\
\text { Beta }\end{array}$} & \multirow[b]{2}{*}{$\mathrm{t}$} & \multirow[b]{2}{*}{ Sig } \\
\hline & B & Std. Error & & & \\
\hline $1 \quad$ (Constant) & 4.580 & 6.952 & & .659 & .513 \\
\hline MOTIVASI & .266 & .181 & .145 & 1.474 & .147 \\
\hline KOMUNIKASI & -.071 & .323 & -.020 & -.221 & .826 \\
\hline $\begin{array}{l}\text { LINGKUNGAN } \\
\text { KERJA }\end{array}$ & 1.473 & .196 & .738 & 7.523 & .000 \\
\hline
\end{tabular}

\section{Pengaruh motivasi terhadap semangat kerja}

Hasil pengujian diperoleh nilai $\mathrm{t}_{\text {hitung }}$ sebesar 1,474 lebih kecil dari $\mathrm{t}_{\text {tabel }}$ maka $\mathrm{H} 0$ diterima dan Ha ditolak, maka tidak ada 
Website : http://mail.unmermadiun.ac.id/index.php/jamer/index

pengaruh positif dan signifikan motivasi terhadap semangat kerja. Hal ini berarti hipotesis (H1) yang menyatakan bahwa motivasi tidak berpengaruh terhadap semangat kerja, diterima.

\section{Pengaruh komunikaii terhadap semangat kerja}

Hasil pengujian diperoleh nilai thitung sebesar -0,221 lebih besar dari - $t_{\text {tabel }}$ sebesar -2,012 maka H0 diterima dan Ha ditolak, maka tidak ada pengaruh positif dan signifikan Komunikasi terhadap Semangat Kerja. Hal ini berarti hipotesis $\left(\mathrm{H}_{2}\right)$ yang menyatakan bahwa Motivasi tidak berpengaruh terhadap Semangat Kerja, diterima.

\section{Pengaruh lingkungan kerja terhadap semangat kerja}

Hasil pengujian diperoleh nilai thitung sebesar 7,523 lebih besar dari $t_{\text {tabel }}$ sebesar 2,012 maka ada pengaruh positif dan signifikan lingkungan kerja terhadap Semangat Kerja. Hal ini berarti hipotesis $\left(\mathrm{H}_{2}\right)$ yang menyatakan bahwa Lingkungan Kerja terhadap Semangat Kerja pada PT global Konstruksi Prakasa Madiun, ditolak.

Tabel 3

Hasil Uji F

\begin{tabular}{|l|c|c|c|c|}
\hline Model & $\mathrm{R}$ & $\mathrm{R}$ Square & \multicolumn{1}{|c|}{$\begin{array}{c}\text { Adjusted R } \\
\text { Square }\end{array}$} & $\begin{array}{c}\text { Std. Error of the } \\
\text { Estimate }\end{array}$ \\
\hline 1 & $.815^{\mathrm{a}}$ & .664 & .642 & 3.34305 \\
\hline
\end{tabular}

Dari hasil pengolahan data di atas terlihat bahwa $F_{\text {hitung }}$ sebesar 30,262 lebih besar dari $F_{\text {tabel }}$ sebesar 3,20 maka variabel Motivasi (X1), Komunikasi (X2), dan Lingkungan Kerja $\left(\mathrm{X}_{2}\right)$ secara simultan memiliki pengaruh yang signifikan terhadap Semangat Kerja (Y) pada PT Global Konstruksi Prakasa Madiun, ditolak.

Tabel 4.

Koefisien Determinasi

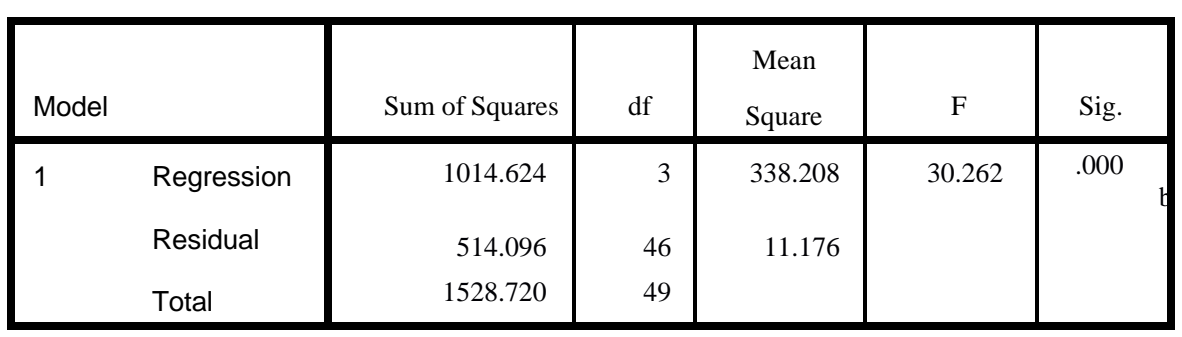

Dari hasil pengolahan data di atas diketahui besarnya Adjuster $R$ Square (Adjusted $\mathrm{R}^{2}$ ) adalah 0,642 atau 64,2\% yang berarti 64,2\% semangat kerja di PT Global Konstruksi Prakasa Madiun dapat dijelaskan oleh variabel motivasi, komunikasi, dan lingkungan kerja sedangkan sisanya yaitu sebesar 35,8\% dijelaskan oleh variabel-variabel yang tidak dimasukkan dalam model penelitian ini.

\section{Pembahasan}

\section{Pengaruh Motivasi ( $\left.\mathrm{X}_{1}\right)$ terhadap Semangat Kerja (Y) PT Global Konstruksi Prakasa Madiun.}

Berdasarkan hasil analisis data diketahui bahwa variabel Motivasi secara parsial tidak ada pengaruh positif dan signifikan terhadap Semangat Kerja. Hal ini berarti hipotesis ( $\mathrm{H} 1)$ yang menyatakan bahwa Motivasi berpengaruh terhadap Semangat Kerja di PT Global Konstruksi Prakasa Madiun tidak terbukti kebenarannya. Hal ini tidak sesuai dengan penelitian yang dilakukan oleh Jaya, dkk (2015) yang menunjukkan bahwa variabel Motivasi memiliki pengaruh positif dan signifikan terhadapkinerja karyawan. Menurut Sitorus (2020) "motivasi kerja adalah segala sesuatu yang menimbulkan gairah, hasrat, keinginan dan energi dari dalam diri seseorang yang mempengaruhi dan mengarahkan serta memelihara perilakunya untuk mencapai tujuan yang diinginkan sesuai dengan lingkup kerja"

Berdasarkan dengan hasil kuesioner yang disampaikan kepada responden penelitin dapat ditarik kesimpulan bahwa motivasi pada PT Global Konstruksi Prakasa Madiun tidak berpengaruh bagi karyawan/pegawai untuk semangat dalam bekerja.Hal ini menunjukkan bahwa kebanyakan responden sudah mengetahui akan Motivasi yang ada dalam diri setiap orang. Hal ini ju g a mengakibatkan variabel Motivasi dalam penelitian ini tidak memiliki pengaruh terhadap Semangat Kerja karena karyawan/pegawai sudah tidak perlu diberi motivasi karena tanpa dimotivasi karyawan sudah memiliki tugas 
dan tanggung jawab masing - masing sehingga hal ini membuat karyawan mau tidak mau harus menyelesaikan pekerjaan dan tanggungjawab tersebut sesuai dengan batas waktu yang sudah ditetapkan.

\section{Pengaruh Komunikasi (X2) terhadap Semangat Kerja (Y) PT Global Konstruksi Prakasa Madiun.}

Berdasarkan hasil analisis data diketahui bahwa variabel Komunikasi secara parsial tidak ada pengaruh positif dan signifikan terhadap Semangat Kerja. Hal ini berarti hipotesis (H1) yang menyatakan bahwa Komunikasi berpengaruh terhadap Semangat Kerja di PT Global Konstruksi Prakasa Madiun tidak terbukti kebenarannya. Hal ini tidak sesuai dengan penelitian yang dilakukan oleh Sugara, dkk (2020) yang menunjukkan bahwa variabel Komunikasi memiliki pengaruh positif dan signifikan terhadap kinerja karyawan. Menurut Ginting (2017) "komunikasi adalah suatu proses pada seseorang yang berusaha untuk memberikan pengertian dan informasidengan cara menyampaikan pesan kepada orang lain"

Berdasarkan hasil kuesioner yang disebarkan peneliti, dapat ditarik kesimpulan bahwa komunikasi tidak memiliki pengaruh sebagai pendorong semangat kerja pada PT Global Konstruksi Prakasa Madiun. Hal ini menunjukkan bahwa komunikasi tidak berpengaruh secara signifikan terhadap kinerja PT Global Konstruksi Prakasa Madiun, artinya apapun yang dilakukan berkaitan dengan komunikasi tidak memiliki pengaruh terhadap semangat kerja karyawan PT Global Konstruksi Prakasa Madiun.

\section{Pengaruh Lingkungan Kerja ( $\left.\mathbf{X}_{3}\right)$ terhadap Semangat Kerja (Y) PT Global Konstruksi Prakasa Madiun.}

Berdasarkan hasil analisis data diketahui bahwa variabel Lingkungan Kerja secara parsial berpengaruh positif dan signifikan terhadap Semangat Kerja. Hal ini berarti hipotesis $(\mathrm{H} 2)$ yang menyatakan bahwa secara parsial lingkungan kerja berpengaruh terhadap Semangat Kerja di PT Global Konstruksi Prakasa Madiun terbukti kebenarannya. Hasil ini sesuai dengan penelitian yang dilakukan oleh Jaya, dkk (2015) yang menunjukkan bahwa Lingkungan Kerja secara parsial berpengaruh positif dan signifikan terhadap Semangat Kerja. Lingkungan kerja disebut suatu tempat bagi sejumlah kelompok di mana di dalamnya terdapat beberapa fasilitas pendukung untuk mencapai tujuan perusahaan sesuai dengan visi dan misi perusahaan (Sedarmayanti, 2017).

Berkaitan dengan kuesioner yang disampaikan dapat ditarik kesimpulan bahwa lingkungan kerja memiliki pengaruh yang besar sebagai pendorong karyawan/pegawai untuk semangat kerja. Hal ini menunjukkan bahwa Lingkungan kerja yang nyaman dapat menjamin pegawai bersemangat dalam bekerja. Hal ini juga menunjukkan bahwa pegawai tersebut memiliki tanggung jawab yang besar sehingga dapat meningkatkan kinerjanya, dengan menambah jumah dan kualitas peralatan kantor yang digunakan sesuai kebutuhan. Perasaan senang yang ditunjukkan oleh pegawai dan kecocokan pegawai dengan peraturan kantor mencerminkan lingkungan kerja yang nyaman.

\section{Pengaruh Motivasi $\left(\mathbf{X}_{1}\right)$, Komunikasi $\left(\mathbf{X}_{2}\right)$ dan Lingkungan Kerja $\left(\mathbf{X}_{3}\right)$ terhadap Semangat Kerja $(\mathbf{Y})$.}

Hasil penelitian menunjukan besarnya Adjuster $R$ Square (Adjusted $\mathbf{R}^{2}$ ) adalah 0,642 atau 64,2\% yang berarti 64,2\% semangat kerja di PT Global Konstruksi Prakasa Madiun dapat dijelaskan oleh variabel motivasi, komunikasi, dan lingkungan kerja sedangkan sisanya yaitu sebesar 35,8\% dijelaskan oleh variabel-variabel yang tidak dimasukkan dalam model penelitian ini. Hal ini menunjukan semua variabel memiliki peran msing-masing dalam mempengaruhi semangat kerja karyawan/pegawaiPT Global Konstruksi Prakasa Madiun

Temuan ini memberikan indikasi bahwa motivasi, komunikasi, dan lingkungan kerja secara bersama sama perlu di perhatikan yang sungguh-sungguh umtuk menjaga serta sekaligus meningkatkan semangat kerja karyawan pada PT Global Konstruksi Prakasa Madiun karena semangat kerja yang tinggi maka akan merangsang seseorang karyawan untuk berkarya dan kreatif dalam pekerjaanya. Hal ini sesuai dengan teori Hasibuan (2010). "Semangat kerja adalah keinginan dan kesungguhan seseorang mengerjakan pekerjaannya dengan baik serta berdisiplin untuk mencapai prestasi kerja yang maksimal, sehingga akan merangsang seseorang untuk berkarya dan kerkreativitas dalam pekerjaannya".

\section{IV.KESIMPULAN}

Berdasarkan analisis data dan pembahasan hasil penelitian di PT Global Konstruksi Prakarsa Madiun maka dapat disimpulkan bahwa, secara parsial motivasi tidak berpengaruh terhadap semangat kerja pada PT Global Kontruksi Prakasa Madiun. Komunikasi secara parsial tidak berpengaruh terhadap semangat kerja pada PT Global Kontruksi Prakasa Madiun. Lingkungan kerja secara secara parsial berpengaruh terhadap semangat kerja pada PT Global Kontruksi Prakasa Madiun. Motivasi, komunikasi, dan lingkungan kerja secara secara simultan berpengaruh terhadap semangat kerja pada PT Global Kontruksi Prakasa Madiun..

\section{DAFTAR PUSTAKA}

Ginting, D. (2017). Komunikasi Cerdas: Panduan Komunikasi di Dunia Kerja (p.157). Jakarta: GramediaHandoko. (2011)a. Manajemen Personalia dan Sumber Daya Manusia (p. 34). Yogyakarta: Liberty.

_ _ _ (2013)b. Manajemen Personalia dan Sumber Daya Manusia (p.65). Yogyakarta: BPFE.

Hasibuan.( 2010). Manajemen Sumber Daya Manusia (p. 75) . Jakarta: PT. Bumi Aksara. 
Website : http://mail.unmermadiun.ac.id/index.php/jamer/index

Jaya Kusuma, I. G. A. I. G. A. S. \& I. N. S. (2015). Pengaruh Lingkungan Kerja dan Motivasi serta Kompensasi Terhadap Semangat Kerja Pegawai Dinas Kesehatan Kabupaten Tabanan. E-Jurnal Ekonomi Dan Bisnis Universitas Udayana, 6(2). Tersedia di: https://webcache.googleusercontent.com/search?q=cache:TxUhabU5CIUJ:https://ojs.unud.ac.id/index.php/EEB/article/view/26820+\&cd=3\&hl=id\&ct=clnk\&gl =id. [diakses pada 24 April 2021 jam 19:37].

Sedarmayanti. (2017). Manajemen Sumber Daya Manusia (p.105). Bandung: Refika Aditam. Siagian, Sondang P. (2018). Manajemen Sumber Daya Manusia (p.14-15). Jakarta: Bumi Aksara.Sinambela, L. P. (2015). Manajemen Sumber Daya Manusia (p. 34). Jakarta: PT.Bumi Aksara.

Sitorus, R. M. T. (2020). Pengaruh Komunikasi Antarpribadi Pimpinan Terhadap Motivasi Kerja (p. 79). Surabaya: Scopindo. Soetjipto, B. W. (2008). Budaya Organisasi dan Perubahan (p.24). Jakarta: PT. Elex Media Komputindo.

Sugara, F. S. A. \& S. C. (2020). Pengaruh Komunikasi, Motivasi, dan Lingkungan Kerja Fisik Terhadap Semangat Kerja Karyawan Ud. Sukri Dana Abadi Ponorogo. Isoquat Jurnal: Ekonomi, Manajemen, Dan Akuntasi, 4(1). Tersedia di:

http://studentjournal.umpo.ac.id/index.php/isoquant/article/view/414. [diakses pada 24 April 2021 jam 20:01]

Wirawan, I. G. K. I. N. S. (2015). Pengaruh Komunikasi, Motivasi dan Lingkungan, Kerja Fisik terhadap Kepuasan Kerja Pegawai Sekretariat Daerah Kota Denpasar. E-Jurnal Manajemen Unud, $\quad 4(10)$. Tersedia di:

https://media.neliti.com/media/publications/250719-pengaruh-komunikasi-motivasi-dan- lingkun-ea81d8f1.pdf. [diakses pada 24 April 2021 jam14:55].

Yahyo. (2013). Pengaruh Motivasi, Lingkungan Kerja dan Kompensasi Terhadap Kinerja Karyawan Melalui Semangat Kerja Karyawan CV. Putra Jaya Sahitaguna, Semarang. Diponegoro Journal of Social and Politic, 2(2). Tersedia di:

https://ejournal3.undip.ac.id/index.php/jiab/article/view/2487. [diakses pada 24 April 2021 jam 16:09] 